University of Wollongong

Research Online

Faculty of Business - Papers (Archive)

Faculty of Business and Law

$1-1-2019$

\title{
Modelling trade-offs in students' choice set when determining universities
}

Andriani Kusumawati

University of Brawijaya, andriani@uow.edu.au

Nelson Perera

University of Wollongong, nperera@uow.edu.au

Venkata K. Yanamandram

University of Wollongong, venkaty@uow.edu.au

Follow this and additional works at: https://ro.uow.edu.au/buspapers

Part of the Business Commons

Research Online is the open access institutional repository for the University of Wollongong. For further information contact the UOW Library: research-pubs@uow.edu.au 


\title{
Modelling trade-offs in students' choice set when determining universities
}

\begin{abstract}
Purpose - The purpose of this paper is to identify the factors influencing Indonesian students' choice of university by estimating the trade-off students make in selecting a university.

Design/methodology/approach - Conjoint analysis was used to examine the relative importance and the part-worth scores of the attributes that influence students' public university preferences in Indonesia.

Findings - High-school leavers in Indonesia trade off university preferences and view advice from family, friends, and/or teachers, reputation, and job prospects as important factors for selecting a public university. Two different preference-based segments of prospective students were identified from cluster analysis, and classified as either a "social networks-based decision" or a "rational decision" segment. A choice simulator was employed with three propositions, and the segments were found to have dissimilar preferences.
\end{abstract}

Research limitations/implications - While this paper provides insights on higher-education consumer choice, more research is needed that includes samples from different types of higher-education institutions and fields of study.

Practical implications - A greater understanding of student choice can help to inform marketing practices and customize marketing strategies for each segment by providing important information to principal parties involved in making university choice decisions.

Originality/value - This paper demonstrates the relevance and value of conjoint analysis as an effective analytical tool for the identification of important choice criteria and its potential contribution to the development of more effective marketing strategies.

\section{Disciplines}

Business

\section{Publication Details}

Kusumawati, A., Perera, N. \& Yanamandram, V. (2019). Modelling trade-offs in students' choice set when determining universities. International Journal of Educational Management, 33 (5), 979-989. 


\section{Modelling Trade-Offs in Students' Choice Set When Determining Universities}

\section{Abstract}

Purpose: This paper identifies the factors influencing Indonesian students' choice of university by estimating the trade-off students make in selecting a university.

Design/methodology/approach: Conjoint analysis was used to examine the relative importance and the part-worth scores of the attributes that influence students' public university preferences in Indonesia.

Findings: High-school leavers in Indonesia trade off university preferences and view advice from family, friends, and/or teachers, reputation, and job prospects as important factors for selecting a public university. Two different preference-based segments of prospective students were identified from cluster analysis, and classified as either a "social networksbased decision" or a "rational decision" segment. A choice simulator was employed with three propositions, and the segments were found to have dissimilar preferences.

Research limitations/implications: While this paper provides insights on higher-education consumer choice, more research is needed that includes samples from different types of higher-education institutions and fields of study. 
Practical implications: A greater understanding of student choice can help to inform marketing practices and customize marketing strategies for each segment by providing important information to principal parties involved in making university choice decisions.

Originality/value: This paper demonstrates the relevance and value of conjoint analysis as an effective analytical tool for the identification of important choice criteria and its potential contribution to the development of more effective marketing strategies.

Keywords: Trade-offs, Higher-education marketing, Student choice, Conjoint analysis

Paper type: Research paper

\section{Background to research}

University choice is a high-involvement decision with a significant level of perceived risk (Briggs, 2006). The social and economic context of higher education makes it important for service providers to understand the preferences of respective customer groups for various product attributes. The relative weightings of importance for each of these attributes provide useful cues to explain why different people make different decisions among a range of choices. Most studies on university choice have required respondents to rate or rank numerous attributes that may influence their preferences (James et al., 1999). While many of such studies were conducted in 'English speaking' universities in 'developed nations' (Lee, 2014; Ahmad and Hussain 2017), a growing stream of studies (Chen, 2008; Al-Fattal and Ayoubi, 2012; Ayoubi and Massoud, 2012; Al-Fattal and Ayoubi 2013; Lee, 2014; Douglas, Douglas, McClelland and Davies, 2015) have sought to narrow and define the preferences in 
contexts outside of the western world. A few other studies have investigated the relative importance of attributes or social class when determining university choice (e.g. Bruce and Edgington, 2008; Callender and Jackson, 2008). These approaches may seem efficient; however, Jackson (1982) argues that it neglects insights into the trade-offs made between attributes.

Complicated trade-offs that naturally occur in the marketplace are captured by conjoint analysis data regarding the decisions of customers who are forced to make difficult choices (Johnson, 1974; Green et al., 2001; Orme, 2005). In such situations, one attribute with good performance often counterweighs other attributes with poor performance (Hagel and Shaw, 2010). Measuring the relative weightings of the attributes may allow a better understanding of the choice behaviour of potential higher education students, which, if taken only one at a time, might not be reliably measurable (Churchill and Iacobucci, 2002).

Several studies have used conjoint experiments to investigate university choice. For example, Hooley and Lynch (1981) identify course suitability, university location, academic reputation, distance from home, type of university (modern/old), and advice from parents and teachers as important factors in students' decisions to enrol in an institution. Moogan et al. (2001) investigated the choices of school leavers and identify the following key decisionmaking attributes: course content, location, and reputation. Dunnett et al. (2012) investigated the impact of fee changes on university choices, focusing particularly on full-cost fees for English undergraduates, and found that students from families with no history of attending university experience more disutility from higher fees than do other groups. Soutar and Turner (2002) also studied the choices made by students from Western Australia, finding that course suitability, academic reputation, job prospects, and teaching quality are the four most 
important determinants of university preference. Each of the experiments required students to make trade-offs between a subset of university attributes including course, academic reputation, and location. More recently, Basha et al. (2016) studied the major influences on Malaysian and Chinese students' preferences for international universities. Their results indicated that Malaysian students prefer to study in the UK, and are more cost sensitive than Chinese students, who favour Australia and are more motivated by the job prospects that an institution offers. While a number of important studies have investigated the student decisionmaking process, at least two important concerns with prior research limit the understanding of university choice, as outlined below.

First, generalizing findings from particular countries and contexts can be based on the mistaken assumption that what works to attract good students for a particular university or country also applies to others (Dao and Thorpe, 2015; Ahmad and Hussain, 2017). There is a need to understand the context of these factors to develop a suitably nuanced marketing response (Kallio, 1995; Kotler and Fox, 1995). Second, most existing studies ask hypothetical questions; that is, they ask respondents to reflect on the key decision-making factors that appear to be important to them, rather than exploring the influences on their choices and any trade-offs in actually choosing a university (Boatwright et al., 1999; Dunn and Wharton, 2003; Hoyt and Brown, 2003; Moogan and Baron, 2003; Kim, 2004; Veloutsou et al., 2004; Dawes and Brown, 2005; Domino et al., 2006; Tatar and Oktay, 2006; Yamamoto, 2006; Brown et al., 2009; Fernandez, 2010; Petruzzellis and Romanazzi, 2010; Dao and Thorpe, 2015; Singh, 2016). Carson et al. (1994) warn against using designs that include dominated alternatives, because the respondent choices do not reveal information about trade-offs between the levels of different attributes. The need to investigate trade-offs in students' decision making lead to three research questions: (1) Do students trade-off between attributes when making 
evaluations of their university preference? (2) What are the relative levels of importance that students attach to the factors that influence them in selecting a university? (3) Are there groups of students for whom different factors are more important?

This paper focuses on providing empirical evidence to better understand the complex situation of decision-making process by potential higher-education students in Indonesia.

\section{Methodology}

The sampling frame consisted of high-school leavers who chose to select a public university. This sampling frame was chosen for two reasons. First, this population makes up the largest segment of universities' prospective students, and they are the major targeted cohort who enters public universities. Second, these individuals can provide accurate information regarding their choice processes because they are in the process of selecting a public university. Indonesian public universities in Java were chosen because that island has the largest population and the greatest number of public universities. Four out of its six provinces were chosen as a sample area based on the level of socio-economic status, the number of students enrolled, and the number of public universities. A judgement sample was drawn for the study based on two criteria: only high-school leavers who were actively engaged in the decision to select public autonomous or non-autonomous universities in Java, and individuals who chose a business and economics study program as their first preference. This was done using a screening question administered before providing the questionnaire to the respondent. To encourage more respondents to participate in the study, and to increase the response rate while preserving respect, the study employed a face-to-face method of distributing the selfadministered questionnaire. Low consistency scores of the validation sample (minimum 
Kendall's $\tau=0.40$ ) eliminated some subjects from the analysis to increase the validity and reliability of the model (Burns and Bush, 2010; Hair et al., 2010). A total of 403 complete responses were collected, and were assumed sufficient to ensure valid and robust interpretation of the results.

The attributes of university preference that were included in the study were identified through a series of preliminary qualitative studies, and validated through a review of the extensive literature. The exploratory study results identify 25 attributes - too many to consider in a conjoint study. While the inclusion of all potentially influential attributes would best describe a hypothetical product, anything in excess of five or six attributes has been argued to diminish the reliability of conjoint output (Green and Srinivasan, 1990). The conjoint questionnaire in this current study was derived from six key variables: total expenses; reputation; proximity; job prospects; advice from family, friends, and/or teachers; and campus atmosphere. A fractional design that involved subsets of the full design was performed (Hair et al., 2010), and SPSS/PASW conjoint 18 was used to reduce the size of the subset (orthogonal array) into 18 combinations of profiles (Ekdahl, 1997). Four holdout cases were added at the end of the conjoint profile list to ascertain the predictive power of the model and to validate the results of the later conjoint analysis. This approach was consistent with the experiment being designed to reflect the final-choice stage, where students have chosen and identified a small set of universities to which they are confident of gaining entry (James et al., 1999; Moogan et al., 2001). A rating scale of 1 to 10, poled from "Do not prefer" to "Do prefer", was used to judge each combination. 


\section{Findings and discussion}

\section{Socio-demographic profile of the respondents}

Consistent with the demographics associated with the population of interest, most of the respondents were aged between 18 and 20 years. More male (217) than female (186) students participated, but there were enough subjects from each gender for the purposes of this study. The majority of participants, (324) graduated from public high schools; 73 graduated from private high schools; and the remaining six respondents graduated from other high schools.

\section{Trade-offs and conjoint analysis findings}

In this study, two conjoint models were developed. First, the aggregate model analysed all 403 responses and assumed homogeneous preferences. Second, the segmented model split the data resulting from cluster analysis into separate segments.

Pearson's $r$ and Kendall's $\tau$ statistics were computed as summary measures of goodness-offit. They are reported as indicators of fit between the model and the obtained data (Green and Rao, 1971; Green and Srinivasan, 1978; 1990; Green et al., 2001), and are very high for this analysis for the aggregate sample (0.997 and 0.967), indicating that this study's analyses are valid. A strong correlation (Kendall's $\tau=0.667$ ) was found between the predicted model and the holdout set, which gives strong confidence in the suitability of the main effects model. Similarly, the entire sample had a high $r$ (above 0.7 ) for the predicted model and a score higher than 0.4 for the holdout set. The results uphold the assumption that high-school students perceive university choice criteria as bundles of attributes, and consider personal constraints when selecting a public university (Table 1). Additionally, the importance scores were computed by dividing the utility range for a particular attribute by the sum of all the utility ranges (SPSS Inc, 2007). These are reported in Table 1. 
Conjoint analysis revealed the following relative importance of attributes for all respondents: (1) advice from family, friends, and/or teachers; (2) reputation; (3) job prospects; (4) total expenses; (5) campus atmosphere; and (6) proximity. Further analysis of the advice from family, friends, and/or teachers suggests a high preference for support in the form of strong recommendations (mean utility $=0.824$ ). If this type of support is unavailable, the students in this sample appear less inclined to attend a university for which their important others express only moderate support (mean utility $=0.187$ ), and may possibly forego a university education if there is no support at all (mean utility $=-1.011)$. As suspected, strong recommendations from family, friends, and/or teachers increased the likelihood of choosing a nearby university. Although respondents did not consider close proximity (mean utility $=0.008$ ) as the highest preference, moderate proximity seemed more reasonable (mean utility $=0.022$ ) for them than greater distance (mean utility $=-0.030)$.

Insert Table 1 here

A closer look at the results revealed that the respondents most preferred average total expenses $($ mean utility $=0.174)$, and demonstrated increasing disutility when total expenses were high $($ mean utility $=-0.143)$ and low $($ mean utility $=-0.031)$. Strong reputation and increased likelihood of finding a good job contributed positively to overall utility. The respondents also demonstrated minimum utility for poor job prospects after graduation (mean utility $=-0.578)$, moderate utility for moderate job prospects (mean utility $=0.22)$, and a strong preference for good job prospects (mean utility $=0.537$ ). The respondents in this study 
also preferred a great campus atmosphere (mean utility $=0.171)$ and showed increasing disutility on average (mean utility $=-0.013$ ) for very little campus atmosphere (mean utility $=-0.158)$.

The results presented for the aggregate model suggest that "reference group influence" including advice from family, friends, and/or teachers - was significantly more important than other factors. A high influence of social links in students' decisions about university choice has been revealed in many studies (Ceja, 2004; Kim and Schneider, 2005; Perna and Titus, 2005). For example, parents of first-generation students (in other words, parents who themselves have not had opportunities to attend college) (Fann et al., 2009), parents of young women students (Al-Yousef, 2009), and siblings of students (Ceja, 2006) became active participants in college preparation and planning. The findings also suggest that the respondents in this study were willing to accept average total expenses, possibly due to concerns about the reputation of the university as well as the quality of education.

Preliminary cluster analysis was performed through a hierarchical method, using Ward's procedure, which was combined with the squared Euclidean distance measure to determine the number of clusters. Then the cluster membership was found by using a non-hierarchical method, the K-means method, as suggested by Perera (2008) and Hair et al. (2010). Cluster analysis identifies two homogeneous student segments. Each group represents a different preference-based segment, and is substantial in size. The smallest segment, representing 19.85 percent of the sample, is labeled the "social networks-based decision" segment; the largest segment, representing 80.15 percent of the sample, is labeled the "rational decision" segment. Again, conjoint analysis was performed on each segment. Table 1 shows what 
variables have the most impact on driving student membership into different segments. The validities of the two clusters were highly correlated: for Cluster 1, Pearson's $r=0.997$ and Kendall's $\tau=0.901$; for Cluster 2, Pearson's $r=0.995$ and Kendall's $\tau=0.961$. The predicted model and the holdout set for each of those two clusters were perfectly correlated (Kendall's $\tau=1.000)$.

As shown in Table 1, the two clusters differ most on the relative importance placed on advice from family, friends, and/or teachers; reputation; and job prospects. The first segment placed the highest importance on advice from family, friends, and/or teachers (relative weight $=$ 60.245 percent $)$, followed by job prospects (8.499 percent) and total expenses (8.296 percent). In contrast to the findings within the aggregate model, reputation was the least important (7.166 percent), and proximity (7.500 percent) the second least important. The second segment rated reputation as most important (relative weight $=21.754$ percent), followed by job prospects (20.599 percent); while proximity was the least important (12.110 percent). This group ranked advice from family, friends, and/or teachers third (16.882 percent), followed by total expenses (15.227 percent). Similar to the aggregate model, campus atmosphere (13.427 percent) and proximity were the least influential (12.110 percent) attributes.

The utility for advice from family, friends, and/or teachers (Table 1) shows that the first segment valued a strong recommendation from family, friends, and/or teachers (mean utility $=2.025)$ and was opposed to another type of support from family, friends, and/or teachers (none/negative support mean utility $=-3.104$ ). Likewise, the second segment also considered strong recommendations from family, friends, and/or teachers as important. As shown in 
Table 1, both segments demonstrated disutility from decreases in group reference recommendations, but the rational decision segment was more price-sensitive. For example, when there was a strong recommendation from their social reference group, prospective students in the first segment may not have been sensitive to a high level of total expenses, even with poor reputation and job prospects. In contrast, the rational decision segment had high expectations of their preferred university (Table 1), selecting a university with a strong reputation, good job prospects, great campus atmosphere, and a strong recommendation from their reference group, but with average total expenses and moderate proximity.

If finding a job is necessary to cover the costs of education, it is not surprising that the two groups also differ significantly on utility for job prospects. Table 1 suggests that the social networks-based decision group was satisfied with poor job prospects after graduation (mean utility $=0.027)$ with either close or moderate distance from home. However, the rational decision segment was not satisfied with only an average level of getting a job offer after graduation, and had a much stronger preference for a good chance of an offer (mean utility = $0.667)$.

\section{Choice simulator}

The final stage of the conjoint analysis is the choice simulator for estimating percent of respondent choice for specific factor profiles entered into the simulator. Most often, the current competitors in the market are identified based on specific levels of the choice attributes. The simulator estimates choice share for the current market. The most common simulator models include the maximum utility (first-choice model), the average-choice (Bradley-Terry-Luce) model, and the logit model. The first-choice model identifies the product with the highest utility as the product of choice. Each respondent is assumed to choose the profile with the highest utility (max-utility choice rule). After the process is 
repeated for each respondent's utility set, the cumulative "votes" for each product are evaluated as a proportion of the votes or respondents in the sample (that is, "market" share). The Bradley-Terry-Luce model estimates choice probability in a different fashion: the choice probability for a given product is based on the utility for that product divided by the sum of all products in the simulated market. The logit model uses an assigned choice probability that is proportional to an increasing monotonic function of the alternative's utility. The choice probabilities are computed by dividing the logit value for one product by the sum for all other products in the simulation. These individual choice probabilities are averaged across respondents. Both probability models tend to give similar predictions (Hair et al., 2010). The SPSS/PASW 18 conjoint simulator uses the holdout profile (for validity and reliability checks) and computes a preference score for each respondent. It offers three choice rules: maximum utility, the Bradley-Terry-Luce probability of choice model, and logit, as presented in Table 2.

\section{Insert Table 2 here}

An ideal preference for the high-school leavers according to this current study is to choose a university with average total expenses (0.174), a good reputation (0.428), and a moderate proximity (0.22). Students preferred to choose a university that was strongly recommended by their family, friends, and/or teachers (0.824), with good job prospects (0.537), and a great campus atmosphere $(0.171)$. In the simulation process, the ideal preference becomes the more realistic university choice criteria presented in Table 3. From the three universities, the most preferable combination for the aggregate sample was University 2 . This university holds the highest probability score in maximum utility for 43.7 percent, Bradley-Terry-Luce for 35.5 
percent, and logit test for 40.8 percent. The proposition consists of an average level of total expenses, reputation, job prospects, and campus atmosphere, with moderate proximity, but strongly recommended by their family, friends, and/or teachers.

\section{Insert Table 3 here}

Simulation conducted with the same three concepts on two different segments found that these segments have dissimilar preferences. Segment 1 places the highest preference on choice criteria (such as low total expenses, average reputation, close proximity, and strong recommendations from family, friends, and/or teachers), although these could appear alongside poor job prospects as well as very little campus atmosphere, as with University C (Table 3). This concept holds the highest probability score in maximum utility for 44.4 percent, Bradley-Terry-Luce for 35.8 percent, and logit test for 41.9 percent (Table 2). In contrast, Segment 2 has more rational choice criteria, selecting University 2 as the highest preference. This university has the highest probability score in maximum utility for 53.8 percent, Bradley-Terry-Luce for 35.8 percent, and logit test for 47.3 percent. This university's characteristics include average total expenses, reputation, job prospects and campus atmosphere, with moderate proximity and a strong recommendation from family, friends, and/or teachers. The results are consistent between Segment 2 and the aggregate sample (Table 2). The results reveal that University A was not at all attractive to any of the segments. This combination shows that, generally, high-school leavers in this research had realistic choice criteria even though they still depended on their social networks' recommendations for selecting their preferred university. 


\section{Conclusion}

This study found that the most important determinant of university choice for Indonesian high-school leavers was advice from family, friends, and/or teachers, which is in contrast to findings from student choices in developed countries. Interestingly, while that attribute rated highest in importance, there was only a small gap between the highest- and lowest-rated attributes. The highest-rated attribute (advice from family, friends, and/or teachers) had a relative importance of 25.490 percent, while the lowest-rated attribute (proximity) had a relative importance of 11.195 percent. This suggests that the students' decision-making process was complicated. While their final choices may have been determined by the most important attributes, they did trade-off between the various attributes when making decisions.

This research confirms that prospective students used a subset of attributes when selecting a university. With the benefit of conjoint analysis, consumer preferences were identified and described in two models, an aggregate and a segmented model, based on the importance values and the part-worth utilities obtained. The results also show that while some students considered high reputation and good job prospects as part of their choice criteria, many continued to identify the strong influence of social networks. A conjoint simulator test allowed the preferences of three university choice scenarios that were not actually rated by consumers to be examined by the aggregate sample and by different segments. These three possible university combinations captured the actual scenario of reputational diversity in the Indonesian public university sector, and represented both "old" and "new" universities. This analysis was also intended to give an insight into the use of conjoint analysis in estimating relative market shares. 
Another outcome of the study is its demonstration of the usefulness of the conjoint analysis approach in overcoming some of the difficulties found in earlier studies, where students often did not, or could not, discriminate between university attributes and evaluate them as a whole. By allowing students to choose between attributes, this study focused attention on a subset of attributes as being important. The results can help university administrators and recruiters customize their marketing strategies for each segment by providing important information to the principal parties involved in making university-choice decisions.

Public universities should deliver on the most important criteria identified by prospective students. Based on the findings of this current study, universities can design the program specifically to involve family members and the community to perpetuate "the notion of cultural capital beyond merely the individual" (Tierney, 2004, p. 228).

As a future research direction, to get a benefit from conducting conjoint analysis based on clustering, surveys can be conducted with specific student segments based on the socioeconomic status of the prospective students, and perhaps in different geographical areas. This could help determine if there are other relevant importance factors. 
Table 1. Average Part-worths and Relative Importance for University-preference Attributes

\begin{tabular}{|c|c|c|c|}
\hline \multirow[b]{2}{*}{ Attribute/Level } & \multicolumn{3}{|c|}{ Relative Importance/Utilities (rank) } \\
\hline & $\begin{array}{l}\text { Aggregate } \\
(n=403)\end{array}$ & $\begin{array}{l}\text { Segment } 1 \\
\quad(n=80)\end{array}$ & $\begin{array}{c}\text { Segment } 2 \\
(n=323)\end{array}$ \\
\hline Total expenses & $13.851 \%(4)$ & $8.296 \%(3)$ & $15.227 \%(4)$ \\
\hline High & -0.143 & 0.025 & -0.185 \\
\hline Average & 0.174 & -0.010 & 0.220 \\
\hline Low & -0.031 & -0.015 & -0.035 \\
\hline Reputation & $18.858 \%(2)$ & $7.166 \%(6)$ & $21.754 \%$ \\
\hline Strong & 0.428 & 0.046 & $\mathbf{0 . 5 2 3}$ \\
\hline Average & 0.188 & -0.102 & 0.260 \\
\hline Poor & -0.616 & 0.056 & -0.783 \\
\hline Proximity & $11.195 \%(6)$ & $7.500 \%(5)$ & $12.110 \%(6)$ \\
\hline Close & 0.008 & $\mathbf{0 . 0 5 0}$ & -0.003 \\
\hline Moderate & $\mathbf{0 . 0 2 2}$ & $\mathbf{0 . 0 5 0}$ & 0.015 \\
\hline Far & -0.030 & -0.100 & -0.012 \\
\hline Job prospects & $18.197 \%$ & $8.499 \%(2)$ & $20.599 \%(2)$ \\
\hline Good & $\mathbf{0 . 5 3 7}$ & 0.010 & 0.667 \\
\hline Average & 0.041 & -0.037 & 0.061 \\
\hline Poor & -0.578 & $\mathbf{0 . 0 2 7}$ & -0.728 \\
\hline Advice from Family, Friends, and/or Teachers & $25.490 \%(1)$ & $60.245 \%(1)$ & $16.882 \%(3)$ \\
\hline Strongly recommended & 0.824 & 2.025 & 0.526 \\
\hline Moderate support & 0.187 & 1.076 & -0.033 \\
\hline None/Negative & -1.011 & -3.104 & -0.493 \\
\hline Campus atmosphere & $12.408 \%(5)$ & $8.294 \%(4)$ & $13.427 \%(5)$ \\
\hline Great & $\mathbf{0 . 1 7 1}$ & $\mathbf{0 . 1 7 7}$ & 0.169 \\
\hline Average & -0.013 & -0.212 & 0.036 \\
\hline Very little & -0.158 & 0.035 & -0.206 \\
\hline Constant & 5.244 & 5.188 & 5.258 \\
\hline Pearson's R & 0.997 & 0.997 & 0.995 \\
\hline Kendall's $\tau$ & 0.967 & 0.901 & 0.961 \\
\hline Kendall's $\tau$ for Holdouts & 0.667 & 1.000 & 1.000 \\
\hline
\end{tabular}


Table 2. Conjoint Attributes and Preference Probabilities of Simulations for Aggregate Sample

\begin{tabular}{|c|c|c|c|c|c|}
\hline \multirow[b]{2}{*}{ Attribute } & \multicolumn{2}{|c|}{ Ideal Preference } & \multicolumn{3}{|c|}{ Attribute Level } \\
\hline & Level & $\begin{array}{c}\text { Utilities } \\
\text { Score } \\
\end{array}$ & University 1 & University 2 & University 3 \\
\hline Total expenses & Average & 0.174 & High & Average & Low \\
\hline Reputation & Strong & 0.428 & Strong & Average & Average \\
\hline Proximity & Moderate & 0.022 & Far & Moderate & Close \\
\hline Job prospects & Good & 0.537 & Good & Average & Poor \\
\hline $\begin{array}{l}\text { Advice from Family, } \\
\text { Friends, and/or } \\
\text { Teachers }\end{array}$ & $\begin{array}{l}\text { Strongly } \\
\text { recommended }\end{array}$ & 0.824 & $\begin{array}{l}\text { Moderate } \\
\text { support }\end{array}$ & $\begin{array}{l}\text { Strongly } \\
\text { recommended }\end{array}$ & $\begin{array}{l}\text { Strongly } \\
\text { recommended }\end{array}$ \\
\hline \multirow[t]{4}{*}{ Campus atmosphere } & Great & 0.171 & Average & Average & Very little \\
\hline & Maxim & Utility & $35.7 \%$ & $43,7 \%$ & $20.6 \%$ \\
\hline & Bradley-T & ry-Luce & $34.5 \%$ & $35.5 \%$ & $30.0 \%$ \\
\hline & & Logit & $35.2 \%$ & $40.8 \%$ & $24.0 \%$ \\
\hline
\end{tabular}

Table 3. Conjoint Preference Probabilities of Simulations for Each Segment

\begin{tabular}{lcccccc}
\hline \multirow{2}{*}{ Attribute } & \multicolumn{3}{c}{ Segment 1} & \multicolumn{2}{c}{ Segment 2 } \\
\cline { 2 - 7 } & $\begin{array}{c}\text { University } \\
\text { A }\end{array}$ & $\begin{array}{c}\text { University } \\
\text { B }\end{array}$ & $\begin{array}{c}\text { University } \\
\text { C }\end{array}$ & $\begin{array}{c}\text { University } \\
\text { A }\end{array}$ & $\begin{array}{c}\text { University } \\
\text { B }\end{array}$ & $\begin{array}{c}\text { University } \\
\text { C }\end{array}$ \\
\hline Maximum Utility & $5.6 \%$ & $40.6 \%$ & $53.8 \%$ & $43.2 \%$ & $44.4 \%$ & $12.4 \%$ \\
Bradley-Terry-Luce & $30.4 \%$ & $34.3 \%$ & $35.8 \%$ & $35.6 \%$ & $35.8 \%$ & $28.6 \%$ \\
Logit & $16.6 \%$ & $36.0 \%$ & $47.3 \%$ & $39.8 \%$ & $41.9 \%$ & $18.2 \%$ \\
\hline
\end{tabular}




\section{References}

Ahmad, S. Z., \& Hussain, M. (2017). An investigation of the factors determining student destination choice for higher education in the United Arab Emirates. Studies in Higher Education, 42(7), 1324-1343.

Al-Fattal, A. and Ayoubi, R.M. (2012). "Understanding Consumer Buyer Behaviour in the EFL Market: a Case Study of a Leading Provider in Syria”, Education, Business and Society: Contemporary Middle Eastern Issues, Vol 5, Issue 4, pp. 237-253.

Al-Fattal, A. and Ayoubi, R.M. (2013) "Students Needs and Motives when Attending a University: Exploring the Syrian Case", Journal of Marketing for Higher Education, Vol 23, Issue 2, pp.204-225.

Al-Yousef, H. (2009), “They know nothing about university-neither of them went”: The effect of parents' level of education on their involvement in their daughters' higher education choices", Compare: A Journal of Comparative and International Education, Vol. 39 No. 6, pp. 783-798.

Ayoubi, R.M. and Massoud, H.K. (2012). "Student Aspiration Factors, University Reputation and the Entry Standards to UK Universities", European Journal of Social Sciences, Vol 34, Issue 4, pp. 609-621. 
Basha, N.K., Sweeney, J.C. and Soutar, G.N. (2016), “International students' university preferences: how different are Malaysian and Chinese students?" International Journal of Educational Management, Vol. 30 No. 2, pp. 197-210.

Boatwright, M.A., Ouimet, J.A. and Middleton, T. (1999), "Can high-choice college set be linked to college-of-enrollment?” College and University, Vol. 75 No. 1, pp. 23.

Briggs, S. (2006), “An exploratory study of the factors influencing undergraduate student choice: the case of higher education in Scotland", Studies in Higher Education, Vol. 31 No. 6, pp. 705-722.

Brown, C., Varley, P. and Pal, J. (2009), "University course selection and service marketing”, Marketing Intelligence \& Planning, Vol. 27 No. 3, pp. 310-325.

Bruce, G., \& Edgington, R. (2008). Factors influencing word-of-mouth recommendations by MBA students: An examination of school quality, educational outcomes, and value of the MBA. Journal of Marketing for Higher Education, 18(1), 79-101.

Burns, A.C. and Bush, R.F. (2010), Marketing Research, 6th edn, Prentice Hall, Upper Saddle River, New Jersey.

Callender, C., \& Jackson, J. (2008). Does the fear of debt constrain choice of university and subject of study?. Studies in Higher Education, 33(4), 405-429.

Carson, R.T., Louviere, J.J., Anderson, D.A. and Arabie, P. (1994), “Experimental Analysis of Choice”, Marketing Letters, Vol. 5 No. 4, pp. 351-368.

Ceja, M. (2004), “Chicana College Aspirations and the Role of Parents: Developing Educational Resiliency", available at: http://www.fresnounified.org/dept/planning/edresearch/Career\%20Preparation\%20Rese 
arch/Chicano\%20College\%20Aspirations\%20and\%20the\%20Role\%20of\%20Parents, \%20Developing\%20Educational\%20Resiliency.pdf (accessed 20 December 2017).

Ceja, M. (2006), "Understanding the role of parents and siblings as information sources in the college choice process of Chicana students", Journal of College Student Development, Vol. 47 No. 1, pp. 87-104.

Chen, L.H. (2008). Internationalization or international marketing? Two frameworks for understanding international students' choice of Canadian universities. Journal of Marketing for Higher Education, 18(1), 1-33.

Churchill, G.A. and Iacobucci, D.J. (2002), Marketing Research: Methodological Foundations, 8th edn, Harcourt College Publishers, Fort Worth.

Dao, M.T.N. and Thorpe, A. (2015), “What factors influence Vietnamese students' choice of university?" International Journal of Educational Management, Vol. 29 No. 5, pp. $666-681$.

Dawes, P.L. and Brown, J. (2005), "The composition of consideration and choice sets in undergraduate university choice: An exploratory study", Journal of Marketing for Higher Education, Vol. 14 No. 2, pp. 37-59.

Domino, S., Libraire, T., Lutwiller, D., Superczynski, S. and Tian, R. (2006), “Higher education marketing concerns: Factors influence students' choice of colleges", The Business Review, Cambridge, Vol. 6 No. 2, pp. 101-111.

Douglas, J., Douglas, A., McClelland. R.J., \& Davies, J. (2015). Understanding student satisfaction and dissatisfaction: An interpretive study in the UK higher education context. Studies in Higher Education, 40(2), 329-349. 
Dunn, C. and Wharton, H. (2003), “The Decision Making Process of Students Entering Higher National Diplomas”, Coventry Business School, Coventry University, available at: http://www.business.heacademy.ac.uk/resources/reflect/conf/2003/dunn/dunn.pdf (accessed 20 December 2017).

Dunnett, A., Moorhouse, J., Walsh, C. and Barry, C. (2012), “Choosing a University: A conjoint analysis of the impact of higher fees on students applying for university in 2012”, Tertiary Education and Management, Vol. 18 No. 3, pp. 199-220.

Ekdahl, F. (1997), “Increased Customer Satisfaction Using Design of Experiments, Conjoint Analysis and QFD”. Thesis, Division of Quality and Technology and Management, Departement of Mechanical Engineering, Linköping University, Linköping.

Fann, A., McClafferty Jarsky, K. and McDonough, P.M. (2009), "Parent Involvement in the College Planning Process: A Case Study of P-20 Collaboration”, Journal of Hispanic Higher Education, Vol. 8 No. 4, pp. 374-393.

Fernandez, J.L. (2010), “An exploratory study of factors influencing the decisions of students to study at Universiti Sains Malaysia”, Kajian Malaysia, Vol. 28 No. 2, pp. 107-136.

Green, P.E., Krieger, A.M. and Wind, Y. (2001), "Thirty Years of Conjoint Analysis: Reflections and Prospects”, Interfaces, Vol. 31 No. 3, pp. S56-S73.

Green, P.E. and Rao, V.R. (1971), “Conjoint measurement for quantifying judgemental data”, Journal of Marketing Research (pre-1986), Vol. 8 No. 000003, pp. 355-363.

Green, P.E. and Srinivasan, V. (1978), “Conjoint Analysis in Consumer Research: Issues and Outlook", The Journal of Consumer Research, Vol. 5 No. 2, pp. 103-123.

Green, P.E. and Srinivasan, V. 1990, “Conjoint analysis in marketing: New developments with implications for research and practice", Journal of Marketing, Vol. 54 No. 4, pp. $3-19$. 
Hagel, P. and Shaw, R.N. (2010), "How Important is Study Mode in Student University Choice?" Higher Education Quarterly, Vol. 64 No. 2, pp. 161-182.

Hair, J.F., Black, W.C., Babin, B.J. and Anderson, R.E. (2010), Multivariate Data Analysis: A Global Perspective, 7th edn, Pearson Education, Upper Saddle River, New Jersey.

Hooley, G.J. and Lynch, J.E. (1981), “Modelling the Student University Choice Process Through the Use of Conjoint Measurement Techniques", European Research, Vol. 9 No. 4, pp. 158.

Hoyt, J.E. and Brown, A.B. (2003), "Identifying college choice factors to successfully market your institution", College and University, Vol. 78 No. 4, pp. 3-10.

Jackson, G.A. (1982), "Public efficiency and private choice in higher education”, Educational Evaluation and Policy Analysis, Vol. 4 No. 2, pp. 237-247.

James, R., Baldwin, G. and McInnis, C. (1999), "Which University? The Factors Influencing the Choices of Prospective Undergraduates, Evaluations and Investigations Programme.” Higher Education Division, Canberra, Australian Government Publishing Service.

Johnson, R.M. (1974), “Trade-off analysis of consumer values”, Journal of Marketing Research (JMR), Vol. 11 No. 2, pp. 121-127.

Kallio, R.E. (1995), "Factors influencing the college choice decisions of graduate students", Research in Higher Education, Vol. 36 No. 1, pp. 109-124.

Kim, D. (2004), “The effect of financial aid on students' college choice: Differences by racial groups", Research in Higher Education, Vol. 45 No. 1, pp. 43-70.

Kim, D.O. and Schneider, B. (2005), "Social Capital in Action: Alignment of Parental Support in Adolescents' Transition to Postsecondary Education”, Social Forces, Vol. 84 No. 2, pp. 1181-1206. 
Kotler, P. and Fox, K.F.A. (1995), Strategic Marketing for Educational Institutions, 2nd edn, Prentice-Hall, Englewood Cliffs, New Jersey.

Lee, C.F. (2014). An investigation of factors determining the study abroad destination choice: A case study of Taiwan. Journal of Studies in International Education, 18(4), 362-381.

Moogan, Y.J. and Baron, S. (2003), "An analysis of student characteristics within the student decision making process", Journal of Further and Higher Education, Vol. 27 No. 3, pp. 271-287.

Moogan, Y.J., Baron, S. and Bainbridge, S. (2001), "Timings and trade-offs in the marketing of higher education courses: a conjoint approach", Marketing Intelligence \& Planning, Vol. 19 No. 3, pp. 179-187.

Orme, B. (2005), Getting Started with Conjoint Analysis: Strategies for Product Design and Pricing Research, 1st edn, Researcher Publishers, Inc, Madison, Wisconsin.

Perera, N. (2008), Data Analysis with SPSS Version 15, 3rd edn, Pearson Education Australia.

Perna, L.W. and Titus, M.A. (2005), “The Relationship between Parental Involvement as Social Capital and College Enrollment: An Examination of Racial/Ethnic Group Differences", The Journal of Higher Education, Vol. 76 No. 5, pp. 485-518.

Petruzzellis, L. and Romanazzi, S. (2010), "Educational value: how students choose university", The International Journal of Educational Management, Vol. 24 No. 2, pp. 139.

Singh, M.K.M. (2016), "Socio-economic, environmental and personal factors in the choice of country and higher education institution for studying abroad among international students in Malaysia”, International Journal of Educational Management, Vol. 30 No. 4, pp. 505-519. 
Soutar, G.N. and Turner, J.P. (2002), “Students' preferences for university: A conjoint analysis", The International Journal of Educational Management, Vol. 16 No. 1, pp. $40-45$.

SPSS Inc. (2007), PASW Conjoint 18. Chicago, SPSS Inc.

Tatar, E. and Oktay, M. (2006), "Search, Choice and Persistence for Higher Education: A Case Study in Turkey”, Eurasia Journal of Mathematics, Science and Technology Education, Vol. 2 No. 2, pp. 115-129.

Tierney, W. (2004), Power, identity, and the dilemma of college student departure, in Braxton, J.M. (Ed.), Reworking the student departure puzzle, Vanderbilt University Press, Nashville.

Veloutsou, C., Lewis, J.W. and Paton, R.A. (2004), “University selection: information requirements and importance", The International Journal of Educational Management, Vol. 18 No. 2/3, pp. 160-171.

Wilkins, S., \& Huisman, J. (2011). International student destination choice: The influence of home campus experience on the decision to consider branch campuses. Journal of Marketing for Higher Education, 21(1), 61-83.

Yamamoto, G.T. (2006), “University evaluation-selection: a Turkish case”, The International Journal of Educational Management, Vol. 20 No. 7, pp. 559-569. 